\title{
Engineering plants against pathogens: A general strategy
}

\author{
F. García-Olmedo , A. Molina, A. Segura, M. Moreno, A. Castagnaro, E. Titarenko, \\ P. Rodriguez-Palenzuela, M. Piñeiro, I. Diaz \\ Laboratorio de Bioquímica y Biología Molecular. E.T.S. Ingenieros Agrónomos. E-28040 Madrid. Spain
}

\begin{abstract}
A general strategy to identify defense proteins and genes and to use them in transgenic plants to engineer enhanced resistance against pathogens is iltustrated with specific experimental examples. A combinatorial model for the expression of defense genes in response to different pathogens is discussed.
\end{abstract}

Keywords: Defence proteins; Hordeum vulgare; Plant diseases; Resistance: disease: Transgenic plants

\section{Introduction}

Plants often accumulate high levels of proteins that are either toxic or inhibitory towards heterologous systems, including pathogens, pests and grazers. This is the case of reserve tissues, where a substantial fraction of the non-storage proteins is represented by different families of defense polypeptides (for reviews, see García-Olmedo et al., 1989, 1992). The same types of proteins are often present in other tissues, either under normal development or under different stresses, including infection by pathogens.

A general strategy has been followed to identify putative defense proteins and to use their genes to engineer plants against pathogens. This strategy involves the following steps: (i) A systematic purifica. tion of cell-wall and vacuolar proteins from different taxa and their screening for antimicrobial properties. (ii) Investigation of in vitro activity against pathogens, including complementation and syner- gism among different defense proteins. (iii) Determination of total or partial amino acid sequences of selected proteins. (iv) Cloning of cDNAs and genomic DNAs encoding these proteins. (v) Study of the expression of these defense genes under normal developmental conditions and under biotic and abiotic stresses. (vi) Transgenic expression of the selected defense genes under appropriate promoters and characterization of the corresponding proteins in the transgenic plants. (vii) Testing of phenotypes with enhanced resistance.

\section{Defense proteins}

In the course of screening different plant species, including wheat, barley, maize, spinach and Arabidopsis, six different families of putative defense proteins have been identified. Two of these, the thionins (THs) and the so-called lipid transfer proteins (LTPs), will be taken as examples to illustrate some of the results of the above approach. Thionins are cysteine-rich polypeptides of about $5 \mathrm{kDa}$ that 
have been found in a variety of tissues from different taxa (see García-Olmedo et al., 1989, 1992). Based on their similarity, known sequences can be grouped into at least 5 clusters or types (I-V), three of which (I, II, V) can be found in cereals such as wheat or barley. The first type, which corresponds to the original purothionins from wheat endosperm (Balls et al., 1942), is 45 residues long, highly basic, with no acid residues, and has four disulfide bridges. There are one or two genes of type I per haploid genome in group-1 chromosomes of wheat and barley genomes. These genes encode precursor proteins in which the sequence of the mature protein is preceded by that of a signal peptide that is co-translationally processed and followed by that of a $\mathrm{C}$ terminal, acidic peptide that undergoes a post-translational excision (Ponz et al., 1983; García-Olmedo et al., 1992). Type-II thionins are less basic, with some acidic residues, and have an extra amino acid located in the central loop, as well as four disulfide bridges (Bohlmann and Apel, 1987; Gausing, 1987). Genes of this type, which seem to be present in 10-100 copies per haploid genome, have been located in chromosome $6 \mathrm{H}$ of barley and encode precursor proteins with the same characteristics as those of type I (Bohlmann and Apel, 1987; Gausing, 1987; Bohlmann et al., 1988). Types III and IV respectively correspond to the viscotoxins and the crambins (for reviews, see García-Olmedo et al., 1989, 1992). Type-III thionins have been described in the mistletoes and type IV in the abyssinian cabbage. Type-V thionins are 37 residues long and have three disulfide bridges, two basic and two acidic residues, and a similar precursor structure as the previous types (Castagnaro et al., 1992). Genes of type V, one copy per haploid genome, have been located within a few kb of type-I genes in group-1 chromosomes in the wheat genomes (Castagnaro et al., 1992).

Members of the LTP family have been characterized in barley aleurone (Mundy and Rogers, 1986) and in green tissues, where we have recently reported a distinct subfamily of at least four members, which are structurally closer to LTPs isolated from other plant species than to the aleurone type (Molina and García-Olmedo, 1991, 1993; Molina et al., 1993). Genes for these LTPs are located in chromosomes $3 \mathrm{H}$ ( $L t p 2$, encoding protein $\mathrm{Cw} 18 ; L t p 4, \mathrm{Cw} 21$ ) and 7H ( Ltp3, Cw20; Molina and García-Olmedo, 1993).
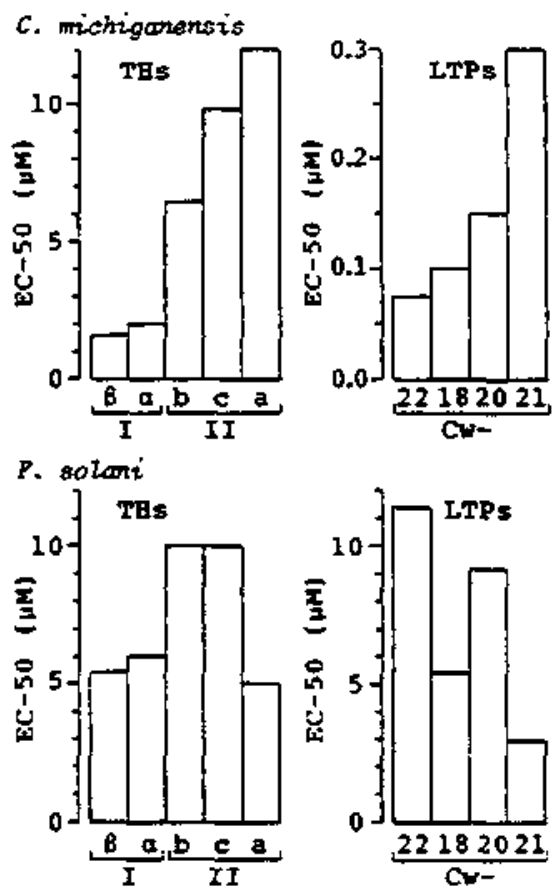

Fig. I. Growth inhibition of the bacterium Clavibacter michiganensis and the fungus Fusarium solani by TH and LTP variants from barley. Effective dose causing $50 \%$ inhibition is represented in each case.

Proteins from the same family have been purified from Arabidopsis and from spinach (Segura et al., 1993).

\section{Activity against pathogens in vitro}

Both THs and LTPs are inhibitory and biocidal (at higher concentrations) towards bacterial and fungal pathogens. It has been shown that thionins are able to alter membrane permeability, indirectly inhibiting macromolecular biosynthesis (Carrasco et al., 1981), and to directly inhibit certain enzymes (Diaz et al., 1992; Piñeiro et al., 1994), while the mechanism of action of LTPs remains unknown. As illustrated in Fig. 1, different THs of types I and II have different activities towards a given pathogen, and the same is true for the barley LTP variants tested, but the relative ranking of the variants changes with the pathogen (i.e. Clavibacter michiganensis versus Fusarium solani). 


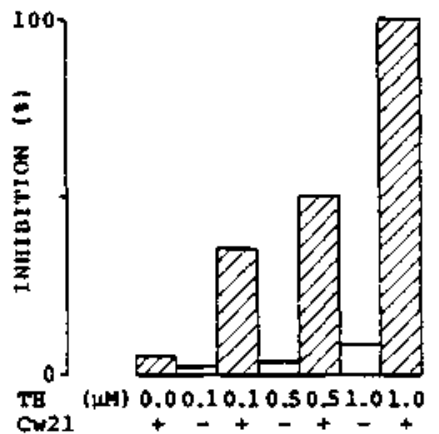

Fig. 2. Synergism of THs (type l) and LTPs (Cw2I; I $\mu \mathrm{M}$ ) against Fusarium solani in vitro.

Data in Fig. 1 also reveal that while LTPs are about 20 -fold more active than THs against the bacterial pathogen, they are somewhat less active than THs against the fungal one, indicating that the two types of proteins could complement each other in vivo to form a general barrier against pathogens. Furthermore, the two types of proteins can act additively against the bacterium (not shown) and synergistically against the fungus (Fig. 2). Complementation, as well as additive and synergic effects, might be relevant to explain interactions in vivo.

Intraspecific variability of pathogen susceptibility to different defense proteins, for which there is some preliminary evidence, and the induction of resistance - including cross resistance - are being actively investigated, both to improve our understanding of compatible/incompatible interactions and because of the relevance of these properties when engineering plants for enhanced resistance.

\section{Expression of defense genes}

Expression patterns of three LTPS and of type-II THs are summarized in Table 1. All tissues tested, except endosperm, expressed the three LTPs investigated, and sequence-specific probes revealed quantitative differences in the expression levels of the three genes. The probe used for the THs (type-II-specific) detected high levels of mRNA in etiolated leaves and lower levels in other tissues. Thionins of types I and $V$ were restricted to endosperm (not shown). The LTPs described here are located in vascular tissues and in the outer cell layer of the exposed surfaces of the plant, and can be eluted from them with high-salt buffer.

Young barley plants were exposed to different physical stresses and treated with different plant hormones and agrichemicals as summarized in Table 2. Steady-state mRNA levels of $L t p$ and $T h$ genes were little affected by the physical treatments, except for moderate responses to salinity of two of the Ltp genes and the response to drought of $T h$ genes. Abscisic acid increased the expression of both types of genes, and methyl jasmonate switched off $L t p$ genes, while markedly increasing the expression of Th genes. All other treatments had no detectable effects.

The current status of the analysis of the expression of these genes in response to pathogens is summarized in Table 3. Responses of the pathogenesis-related gene $\mathrm{PrH} v \mathrm{l}$ from barley (probe gift of $\mathrm{W}$. Knogge, see Hahn et al., 1993) are also indicated.

Table ]

Expression patterns of of $L p$ and $T h$ genes in barley

\begin{tabular}{|c|c|c|c|c|c|c|}
\hline \multirow[t]{2}{*}{ Tissue } & & \multirow[t]{2}{*}{ Age } & \multicolumn{4}{|l|}{ Genes } \\
\hline & & & $L s p 2$ & $L i p\}$ & Ltp4 & $T h$ \\
\hline Root & & young & $(+)$ & $(+)$ & $(+)$ & $(+)$ \\
\hline Leaf & $\begin{array}{l}\text { dark } \\
\text { light }\end{array}$ & $\begin{array}{l}\text { young } \\
\text { young } \\
\text { old }\end{array}$ & $\begin{array}{l}++ \\
++ \\
+\end{array}$ & $\begin{array}{l}++ \\
++ \\
+\end{array}$ & $\begin{array}{l}++ \\
+++ \\
(+)\end{array}$ & $\begin{array}{l}+++++ \\
+ \\
(+)\end{array}$ \\
\hline Shoot apex & & & + & ++ & + & +++ \\
\hline Stem & & $\begin{array}{l}\text { young } \\
\text { old }\end{array}$ & $\begin{array}{l}+++ \\
+\end{array}$ & $\begin{array}{l}+++ \\
+\end{array}$ & $\begin{array}{l}+++++ \\
+\end{array}$ & $\stackrel{+}{(+)}$ \\
\hline Spike & $\begin{array}{l}\text { palea-lemma } \\
\text { grain coats } \\
\text { rachis } \\
\text { endosperm }\end{array}$ & & $\begin{array}{l}(+) \\
(+) \\
(+) \\
-\end{array}$ & $\begin{array}{l}++ \\
+++ \\
++ \\
-\end{array}$ & $\begin{array}{l}+ \\
++ \\
+ \\
-\end{array}$ & $\begin{array}{l}(+) \\
- \\
(+) \\
-\end{array}$ \\
\hline
\end{tabular}

\footnotetext{
- After overnight exposure; parentheses indicate 5-d exposure.
} 
Table 2

Responses $^{2}$ of $L i p$ and $T h$ genes to abiotic stimuli

\begin{tabular}{|c|c|c|c|c|}
\hline \multirow[t]{2}{*}{ Stimuli (conditions) } & \multicolumn{4}{|c|}{ Genes } \\
\hline & $\operatorname{Lip} 2$ & $\operatorname{Ltp} 3$ & $\operatorname{Lip} 4$ & $T h$ \\
\hline Salinity $(0.34 \mathrm{M} \mathrm{NaCl}, 1$ d) & 2 & - & 2 & - \\
\hline $\operatorname{Cold}\left(4^{\circ} \mathrm{C}, 7 \mathrm{~d}\right)$ & - & - & - & - \\
\hline Drought (ovemight) & - & - & - & 4 \\
\hline Wounding ( l d) & - & - & - & - \\
\hline Methyl jasmonate $(10 \mu \mathrm{M}, \mathrm{I} d)$ & 0.05 & 0.06 & 0.12 & 20 \\
\hline Abscisic acid $\left(0.1 \mathrm{mM}_{\mathbf{l}} \mid \mathrm{d}\right)$ & 5 & 2 & 3 & 3 \\
\hline Ethylene ( $100 \mathrm{ppm}, 2 \mathrm{~d})$ & - & - & - & - \\
\hline Ethephon (20 mM, $4 \mathrm{~d}$ ) & - & - & - & - \\
\hline Salicylate (1 mM, $3 \mathrm{~d})$ & - & - & - & $\rightarrow$ \\
\hline Isonicotinic acid (3000 ppm, $1 \mathrm{~d})$ & - & - & - & 2 \\
\hline
\end{tabular}

${ }^{a}$ Level of mRNA compared with normal (fold); -, no effect.

Different combinations of the genes investigated were affected in the different plant/pathogen interactions, and the extent and time-courses of the observed effects were also different. Thus, in the infection by Erysiphe graminis, both LTPs and THs were synchronously affected within the first few hours, before the progress of the compatible and the incompatible interactions can be distinguished microscopically from each other, according to Boyd (1993), which implies either that the response of these genes is irrelevant (gratuitous) in this particular interaction or that sensitivity to the gene products is higher in the avirulent strain. In the infection with Rhyn-
Table 3

Responses of LIPs and Th genes to pathogens

\begin{tabular}{lllllll}
\hline Pathogen/cultivar & $\mathrm{C} / 1^{\mathrm{b}}$ & \multicolumn{2}{l}{ Genes } \\
\cline { 3 - 7 } & & Lip2 & Ltp3 & Ltp4 & Th & PrHuI \\
\hline E. graminisc & & & & & & \\
(Av6)/Pallas & I & 3 & 3 & 9 & 3 & 6 \\
(vir6)/Pallas & $\mathrm{C}$ & 3 & 3 & 8 & 3 & 6 \\
R. seculis & & & & & & \\
/Atlas46 & I & 3 & - & 10 & 4 & 10 \\
/Atlas & $\mathrm{C}$ & - & - & - & 4 & - \\
/Turk & $\mathrm{I}$ & 4 & - & 16 & - & 20 \\
/Hannchen & $\mathrm{C}$ & - & - & - & - & - \\
P. syringae & & & & & & \\
(153)/Bomi & $\mathrm{I}$ & - & - & - & - & - \\
(DC3000)/Bomi & $\mathrm{C}$ & - & - & - & 5 & 4 \\
\hline
\end{tabular}

a Level of mRNA compared with nomal (fold).

${ }^{b} \mathrm{C} / \mathrm{l}$, compatible / incompatible.

c Filters from L. Boyd (Norwich) and " W. Knogge (Cologne)

chosporium secalis, LTPs were rapidly affected and THs lagged behind by 2 days and the response of the Ltp genes was much greater in the incompatible interaction. In the case of Pseudomonas syringae, no hypersensitive reaction was detected in the incompatible interaction and none of the genes investigated was expressed above basal levels. This basal resistance was likely due to constitutive levels of defense proteins active against the pathogen.

Recent evidence from our laboratory (Moreno et

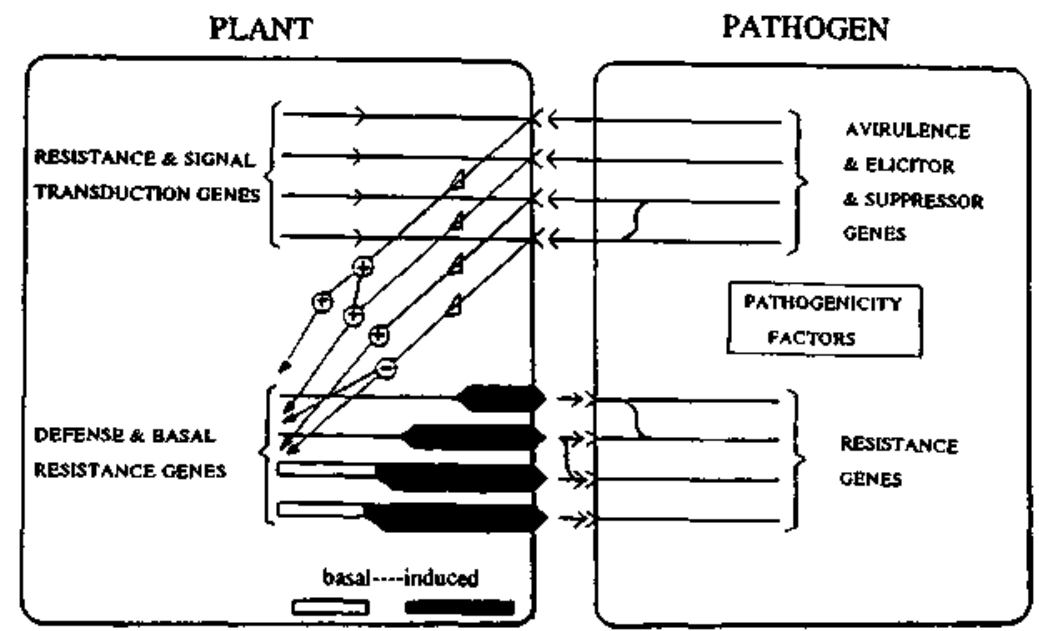

Fig. 3. Schematic representation of a model for the activation/inactivation of defense genes. Multiple signal transduction pathways, which lead to increases $(+)$ or decreases $(-)$ of gene expression, are represented. 
at. 1994) and from others (Kunoh, 1987; Jacobek et al., 1993) indicates that both bacteria and fungi may turn off basal expression levels of certain defense genes, a mechanism by which basal resistance can be evaded by the pathogen.

\section{A combinatorial model of defense responses}

The above observations suggest a number of features related to defense proteins that can be incorporated to current models of plant/pathogen interactions (Fig. 3). These can be summarized as follows: (a) Different defense genes can be activated through totally or partially independent pathways and/or receptors, a combination of which is activated by a given pathogen in the same or in different sets of plant cells. (b) Defense genes which are expressed at a basal level under normal development can be turned off by pathogen signals of suppression. This mechanism might be partially responsible for the combinatorial response. (c) The elicited response might be gratuitous if the elicited proteins are not inhibitory (individually or in combination) against a particular pathogen, which is nevertheless sensed by the plant. (d) A compatible interaction might result not only from failure of the plant to recognize a particular pathogenic strain, and to aclivate the appropriate defense gene(s), but also from the ability of the specific strain to resist inhibitor(s) to which other strains are susceptible. (e) Basal levels of defense proteins (for which additional roles in development are not excluded) are often above $1 \times 10^{-5}$ moles $/ \mathrm{kg}$ fresh weight, concentrations that should be sufficient to inhibit growth of many pathogens by a mechanism that does not imply a hypersensitive reaction. (f) The same defense proteins might be involved in all the different situations described above (b-e).

\section{Enhanced resistance in transgenic plants}

We have expressed different combinations of defense genes under various promoters and, as exemplified in a recent publication concerning the transgenic expression in tobacco of a type-I thionin gene from barley (Carmona et al., 1993), we have shown that enhanced resistance can be achieved through the expression of alien defense genes in new genetic backgrounds which previously lacked equivalent genes.

\section{Outlook for the proposed strategy}

Results summarized in this communication attest the feasibility of the proposed experimental strategy not only to identify novel classes of defense proteins and genes, but also to obtain transgenic plants with enhanced resistance. This last aspect not only contributes to the corroboration of a defense role for a particular protein, but is the basis for practical applications.

\section{Acknowledgements}

The collaboration of W. Knogge and coworkers (Cologne) and of L. Boyd and coworkers (Norwich), as well as financial support from the Comisión Interministerial de Ciencia y Tecnología (grant BIO90/0084) are gratefully acknowledged.

\section{References}

Balls, A.K., Hale, W.S. and Harris, T.H., 1942. A crystalline protein obtained from a lipoprotein of wheat flour. Cereal Chem., 9: 279-288.

Bohlmann, H. and Apel, K., 1987. Isolation and characterization of cDNAs coding for leaf-specific thionins closely related to the endosperm-specific hordothionin of barley (Hordeum rialgare). Mol. Gen. Genet., 207: 446-454,

Bohlmann, H., Clausen, S., Behnke, S., Giese, H., Hiller, C., Reiman-Philipp, U., Schrader, G., Barkholt, V. and Apel, K., 1988. Leaf-specific thionins of barley - a novel class of cell wall proteins toxic to plant-pathogenic fungi and possibly involved in the defense mechanism of plants. EMBO J., 7: $1559-1565$

Boyd, L., 1993. Gene expression in barley in response to mildew infection. In: G. Bruening, F. García-Olmedo and F. Ponz (Editors), Engineering Plants against Pests and Pathogens. Proc. Juan March Workshop, Madrid, Spain, p. 83.

Camona, MJ., Molina, A., Fernandez, J.A., Lopez-Fando, J.J. and García-Olmedo, F., 1993. Expression of the $\alpha$-thionin gene from barley in tobacco confers enhanced resistance to bacterial pathogens. Plant J., 3: 457-462.

Carrasco, L., Vazquez, D., Hernandez-Lucas, C., Carbonero, P. 
and García-Olmedo, F.. 1981. Thionins: plant peptides that modify membrane permeability in cultured mamtmalian cells. Eur. J. Biochem., 116; 185-189.

Castagnaro, A., Maraña, C.. Carbonero, P. and García-Olmedo, $F$., 1992. Extreme divergence of a novel wheat thionin generated by a mutational burst specifically affecting the mature protein domain of the precursor. J. Mol. Biol., 224: 1003-1009.

Diaz. I., Carmona, M.J. and García-Olmedo, F., 1992. Effects of thionins on $\beta$-glucuronidase in vitro and in plant protoplasts. FEBS Lett., 296: 279-282

García-Olmedo, F., Rodriguez-Palenzuela. P., Hemandez-Lucas, C., Ponz, F., Maraña, C., Carmona, M.J., Lopez-Fando, J.J.. Fernandez, J.A. and Carbonero, P., 1989. The thionins: a protein family that includes purothionins, viscotoxins and crambins. Oxford Surveys Plant Mol. Cell Biol., 6: 3l-60.

García-Olmedo, F., Carmona, M.J., Lopez-Fando, J.J., Fernandez. J.A. Castagnaro, A., Molina, A., Hemandez-Lucas, C. and Carbonero, P., 1992. Characterization and analysis of thionin genes. In: T. Boller and F. Meins (Editors), Genes Involved in Plant Defense. Plant Gene Research. Springer-Verlag. Berlin. pp. 283-302.

Gausing, K., 1987. Thionin genes specifically expressed in barley leaves. Planta, 171: 241-246.

Hahn, M., Jüngling, S. and Knogge. W., 1993. Cultivar-specific elicitation of barley defense reactions by the phytotoxic peptide NIP1 from Rhynchosporium secalis. Mol. Plant Microb. Interactions, 6: 745-754.

Jacobek, J.L., Smith, J.A. and Lindgren, P.B., 1993. Suppression of bean defense responses by Pseudomonas syringae. Plant Cell, 5: 57-63.

Kunob, H., 1987. Induced susceptibility and enhanced resistance at the cellular level in barley coleoptiles. In: S. Nishimura
(Editor), Molecular Determinants of Plant Diseases. Japan Sci Soc. Press, Tokyo/Springer-Vexlag, Berlin, pp. 59-63.

Molina, A. and García-Otmedo, F., 1991. Patent application P 910t258 (24.05.9J), Agencia de la Propiedad Industrial, Spain. PCT/EP92/01130, World Intellectual Propeny Organization.

Molina, A. and García-Olmedo, F., 1993. Developmental and pathogen-induced expression of three genes encoding lipid transfer proteins in barley. Plant J., 4: 983-991.

Molina. A., Segura, A. and García-Olmedo, F., 1993. Lipid transfer proteins (nsLTPs) from barley and maize leaves are potent inhibitors of bacterial and fungal plant pathogens. FEBS Lett., 316: 119-122.

Moreno, M.. Segura, A. and García-Olmedo. F., 1994. Pseudothionin-St 1, a potato peptide active against potato pathogens. Eur. J. Biochem., 223: 135-139.

Mundy, J. and Rogers, J.C., 1986. Selective expression of a probable $\alpha$-anylase /protease inhibitor in barley aleurone cells: comparison to the barley $\alpha$-amylase/subtilisin. Planta, 169: $51-63$.

Piñeiro, M. García-Olmedo, F. and Diaz, 1., 1994. Redox modulation of the expression of bacterial genes encoding cysteine-rich proteins in plant protoplasts. Proc. Natl. Acad. Sci. USA, 91: $3867-3871$

Ponz, F., Paz-Ares, J., Hernandez-Lucas, C., Carbonero, P. and Garcia-Olmedo, F., 1983. Synthesis and processing of thionin precursors in developing endosperm from barley (Hordeum iugare L.). EMBO J., 2: 1035-1040.

Segura, A., Moreno, M. and García-Olmedo, F., 1993. Purification and antipathogenic activity of lipid transfer proteins (LTPs) from the leaves of Arabidopsis and spinach. FEBS Lett. 332: $243-246$. 